\title{
Management of Early Blight of Potato by Using Different Bioagents as Tuber Dressing and its Effect on Germination and Growth
}

\author{
Anurag Shukla* and Ved Ratan \\ Department of Plant Pathology C.S.A.U.A.T, Kanpur, India \\ *Corresponding author
}

\section{A B S T R A C T}

\begin{tabular}{|c|}
\hline Keywords \\
\hline $\begin{array}{l}\text { Alternaria solani, } \\
\text { Germination } \\
\text { percent, Tuber } \\
\text { dressing, Plant } \\
\text { height, Rhizobium }\end{array}$ \\
\hline Article Info \\
\hline $\begin{array}{l}\text { Accepted: } \\
15 \text { May } 2019 \\
\text { Available Online: } \\
\text { 10 June } 2019\end{array}$ \\
\hline
\end{tabular}

\section{Keywords}

Alternaria solani, percent, Tuber dressing, Plant Article Info

\section{Introduction}

Early blight of potato is caused by Alternaria solani (Ell. and Mart.) Jones and Grout is one of the most important foliar diseases which are distributed worldwide (1). The pathogen can survive in soil, infested crop and on several weed hosts. Several management practices like host resistance, cultural adjustments, biological management and use of fungicides have been adopted so far to minimize the disease. Cultural practice like field sanitation, summer ploughing, soil

\begin{abstract}
Early Blight of potato is caused by Alternaria solani (Ell. and Mart.) Jones and Grout is one of the most serious diseases of potato. Several management practices have been adopted so far to minimize the disease. But in present investigation based on laboratory and glass house condition revealed that soil application with Farm Yard Manure (FYM) tuber seed dressing with bio-formulation provided higher germination, excellen gr. 83.33 and minimum germination inhibition percent is 16.67 in treatment 5 in which soil is treated with FYM and tuber are treated with Trichoderma harzianum @ 5\%, the growth parameters i.e. plant height is also maximum in the same treatment. The minimum germination percent is 50.00 and minimum germination inhibition percent is 50.00 in treatment $2^{\text {nd }}, 4^{\text {th }}$ and $7^{\text {th }}$ in which soil is treated with FYM and tubers are treated with Rhizobium@5\%,Rhizobium @ 0.05\% and Gypsum @0.2\% respectively. The minimum plant height is in treatment 9, in which soil is treated with FYM and tubers are treated with Trichoderma viride @ 5\% with respect to control.
\end{abstract}

solarisation, soil amendments and crop rotation etc can minimize the possibility of disease but cannot completely control the disease in standing crops. (2) reported several chemicals effective against the pathogen. (3) suggested various management practices using organic and inorganic chemicals. (4) reported various need based management practices at different stages of crop growth. The use resistant variety is another important as well as reliable and cheap for management of plant disease but due to development of new races of pathogen, the resistant variety 
becomes susceptible one. Another alternative method of disease management strategy is biological control using Trichoderma viride, Trichoderma harzianum, Rhizobium, Azatobacter, Gypsum etc. These bio-agents give higher tuber germination and plant height in early blight susceptible variety like Kufri Bahar.

\section{Materials and Methods}

The present investigation was done at the Department of Plant Pathology, Chandra Shekhar Azad University of Agriculture and Technology Kanpur during 2015-2016. The procedure and techniques applied during the course of investigations were elucidated as below.

\section{Isolation, Purification, Identification and Maintenance of Alternaria solani}

Early blight infected leaves were collected from the potato field at Vegetable Research Farm, C. S. Azad University of Agriculture and Technology, Kanpur. The leaves were microscopically examined to confirm the presence of the fungus. After confirming, the presence of fungal spores, isolation was done by following standard tissue isolation method. The infected leaves showing typical symptoms were cut into small bits in such a way that each bit contains infected portions along with some healthy parts. The leaf bits were then surface sterilized with 0.1 per cent mercuric chloride solution for one minute. The bits were washed repeatedly thrice in sterile distilled water and transferred them to sterile petri plates containing PDA (Potato Dextrose Agar) and also on slants under aseptic conditions and incubated at room temperature $\left(25 \pm 10^{\circ} \mathrm{C}\right)$ for 3 to 7 days. It was then observed periodically for fungal growth and sporulation. The purified pathogen was then identified on the basis of its morphological and cultural characteristics.

\section{Collection of bio - fertilizers}

All these bio-fertilizers were collected from Department of Soil Science and Plant Pathology, Chandra Shekhar Azad University of Agriculture \& Technology, Kanpur to conduct the present study. The experiment was conducted in pots having 10 treatments including control and with three replications in the Glass house complex of Department of Plant Pathology, C.S. Azad University of Agriculture and Technology, Kanpur during Rabi season 2015-16. Completely Randomized Design (CRD) is used for the analysis of this experiment.

\section{Collection of seed tuber}

Truly labeled potato seed tubers of variety "Kufri Bahar" was collected from Vegetable Research Farm C.S.A. University of Agriculture \& Technology, Kanpur to conduct the experiment. This Kufri Bahar variety is susceptible for early blight caused by pathogen Alternaria solani.

\section{Addition of farm yard manure}

The soil used to fill the pots is sterilized and added with 1000 gram of fully decomposed farm yard manure and thoroughly mixed.

\section{Tuber treatment with bio-agent}

The packets of Azotobacter and Rhizobium containing 200gm inoculation were obtained from Department of Soil Science, Chandra Shekhar Azad University of Agriculture \& Technology, Kanpur. Six tubers are sown in each pot after treated with its respective bioagent shown in Table 1 and Figure 1.

\section{Tuber germination}

Soil amendments with FYM and tuber treated with bio-agent to find out their effect on 
germination under glasshouse condition. As the seedling begins to emerge from soil, germination percent was calculated by recording the no. of emerging seedling at every 24 hrs interval up to 10 days.

\section{Growth parameter}

The effect soil amendment with FYM and tuber treatment with its respective bio-agent on plant height of potato plants were calculated under glass house complex in pot culture experiment. The observations of plant height were taken from germination to 30 days age of plant shown in Table 2 and Figure 2.

\section{Results and Discussion}

Effect of FYM as soil amendment and bioagents as tuber dressing on germination

The result in the Table 1 and Figure 1, designated that the highest germination per cent was eminent in soil which is amended with farm yard manure + tubers treated with Trichoderma harzianum @ 5\% and soil with farm yard manure + tubers treated with Trichoderma viride @ 5\% representing 83.33 $\%$ each, followed by treatment having soil with farm yard manure + azatobacter representing $66.66 \%$ and treatment having soil with farm yard manure + Rhizobium and treatment having soil with farm yard manure + gypsum representing $50 \%$ which is the lowest (5) similar findings was reported by Horsfall and Lukens (1971).

Effect of FYM as soil amendment and bioagents as tuber dressing on growth parameters (plant height)

The effect soil amendment + tuber treatment on plant height of potato plants were calculated under glass house complex in pot culture experiment. The observations of plant height were taken from germination to 30 days age of plant. The result in Table 2 and Figure 2, specified that the plant height of potato was maximum in T5 treatment having farm yard manure was given as soil application and Trichoderma harzianum for tuber treatment contributes the value of $41.90 \mathrm{~cm}$. The seed tubers of $\mathrm{T} 4$ treatment having farm yard manure as soil application and rhizobium for tuber treatment showing value $40.60 \mathrm{~cm}$ plant height representing second highest among the treatments.

The T3 treatments which are farm yard manure as soil application and azatobacter for tuber treatment showing value $40.30 \mathrm{~cm}$ plant height and become 3rd highest in plant height. The seed tubers of T9 treatment, having farm yard manure as soil amendment and Trichoderma viride as tuber treatment showing value of $38.70 \mathrm{~cm}$ representing the lowest among all the treatments.

In conclusion, the pathogen Alternaria solani was isolated from potato leaves showing typical early blight symptoms. The fungus growing on potato extract media produced white colored mycelium, having large, long beaked and concatenated spores. The description of the fungus agreed with the description given by Common wealth Mycological Institute, Kew, Surrey, England. Thus the pathogen causing early blight of potato has been identified as Alternaria solani. Successful pathogenicity of the fungus on potato was proved following Koch's postulates by inoculating the spore suspension.

Among the different bio-agents tested on germination percent, the maximum percent is 83.33 was recorded at $5 \%$ concentration of each $T$. harzianum and $T$. viride followed by $66.66 \%$ given at $25 \%$ concentration by Azatobacter. 
Table.1 Effect of soil amendments with FYM and tuber treatment on germination

\begin{tabular}{|c|c|c|c|c|}
\hline Treatment & $\begin{array}{l}\text { No of } \\
\text { tubers } \\
\text { sown }\end{array}$ & $\begin{array}{l}\text { Avg. no. of } \\
\text { tubers } \\
\text { germinate }\end{array}$ & $\begin{array}{l}\text { Germination } \\
\text { Percent }\end{array}$ & $\begin{array}{l}\text { Germination } \\
\text { Inhibition } \\
\text { Percent }\end{array}$ \\
\hline $\begin{array}{c}\text { Soil application with FYM + tuber } \\
\text { treated with Trichoderma viride @ } \\
5 \%\end{array}$ & 6 & 5 & 83.33 & 16.67 \\
\hline $\begin{array}{l}\text { Soil application with FYM + tuber } \\
\text { treated with Rhizobium @ 5\% }\end{array}$ & 6 & 3 & 50.00 & 50.00 \\
\hline $\begin{array}{l}\text { Soil application with FYM + tuber } \\
\text { treated with Azatobacter @ 25\% }\end{array}$ & 6 & 4 & 66.66 & 20.00 \\
\hline $\begin{array}{l}\text { Soil application with FYM + tuber } \\
\text { treated with Rhizobium @ 0.05\% }\end{array}$ & 6 & 3 & 50.00 & 50.00 \\
\hline $\begin{array}{c}\text { Soil application with FYM + tuber } \\
\text { treated with Trichoderma } \\
\text { harzianum@ 5\% }\end{array}$ & 6 & 5 & 83.33 & 16.67 \\
\hline $\begin{array}{l}\text { Soil application with FYM + tuber } \\
\text { treated with Azatobacter @ 25\% }\end{array}$ & 6 & 4 & 66.66 & 33.34 \\
\hline $\begin{array}{l}\text { Soil application with FYM + tuber } \\
\text { treated with Gypsum@ 0.2\% }\end{array}$ & 6 & 3 & 50.00 & 50.00 \\
\hline $\begin{array}{c}\text { Soil application with FYM + tuber } \\
\text { treated with Trichoderma } \\
\text { harzianum@ } 5 \%\end{array}$ & 6 & 5 & 83.33 & 16.67 \\
\hline $\begin{array}{c}\text { Soil application with FYM + tuber } \\
\text { treated with Trichoderma viride@ } \\
5 \%\end{array}$ & 6 & 5 & 83.33 & 16.67 \\
\hline Soil application with FYM only & 6 & 2 & 33.33 & 66.67 \\
\hline
\end{tabular}

Table.2 Effect of soil amendments with FYM and tuber treatment on growth parameters of potato at different days of interval (glass house condition)

\begin{tabular}{|c|c|c|c|c|c|c|}
\hline Treatment & $\mathbf{5}$ days & $\mathbf{1 0}$ days & $\mathbf{1 5}$ days & $\mathbf{2 0}$ days & $\mathbf{2 5}$ days & $\mathbf{3 0}$ days \\
\hline T1 & 2.00 & 7.70 & 13.10 & 21.98 & 32.30 & 40.15 \\
\hline T2 & 2.40 & 7.72 & 13.23 & 21.15 & 32.48 & 40.20 \\
\hline T3 & 2.43 & 7.73 & 13.33 & 21.20 & 32.80 & 40.30 \\
\hline T4 & 2.46 & 7.76 & 13.76 & 21.36 & 32.86 & 40.60 \\
\hline T5 & 2.53 & 8.10 & 14.83 & 22.53 & 33.40 & 41.90 \\
\hline T6 & 1.82 & 7.40 & 13.00 & 21.06 & 32.50 & 40.10 \\
\hline T7 & 1.37 & 6.96 & 12.46 & 20.95 & 32.43 & 39.20 \\
\hline T8 & 1.42 & 7.10 & 12.92 & 21.05 & 32.45 & 39.90 \\
\hline T9 & 1.13 & 6.73 & 12.13 & 20.50 & 32.40 & 38.70 \\
\hline T10 & 1.03 & 6.10 & 12.80 & 21.50 & 32.10 & 38.20 \\
\hline CD & 0.120 & 0.455 & 0.815 & 1.623 & 3.235 & 4.852 \\
\hline SEm & 0.040 & 0.153 & 0.274 & 0.444 & 0.678 & 0.831 \\
\hline SEd & 0.057 & 0.216 & 0.388 & 0.628 & 0.959 & 1.176 \\
\hline CV & 3.764 & 3.617 & 3.611 & 3.607 & 3.607 & 3.607 \\
\hline
\end{tabular}


Fig.1 Effect of soil amendments with FYM and tuber treatment on germination

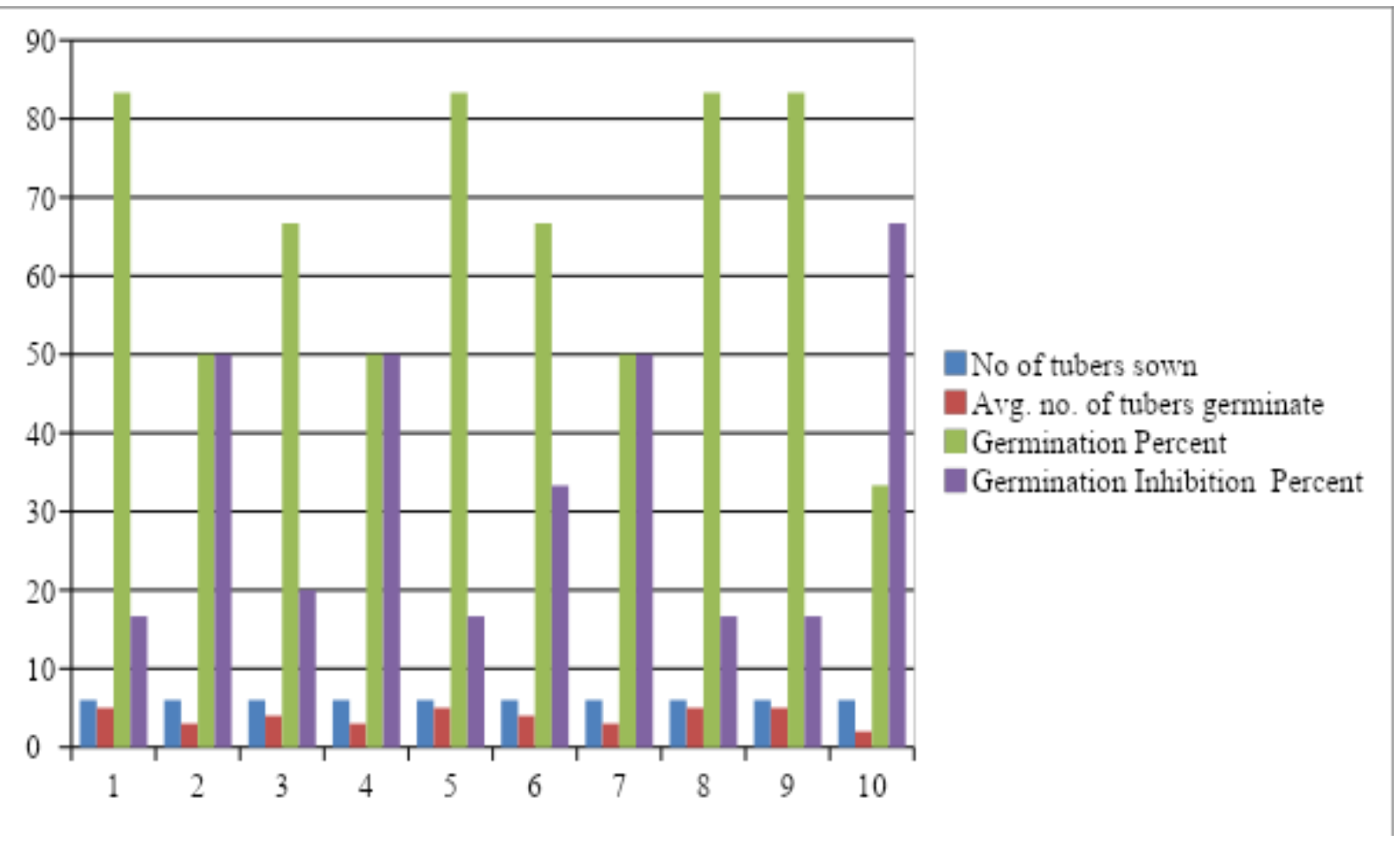

Fig.2 Effect of soil amendments with FYM and tuber treatment on growth parameters of potato at different days of interval (glass house condition)

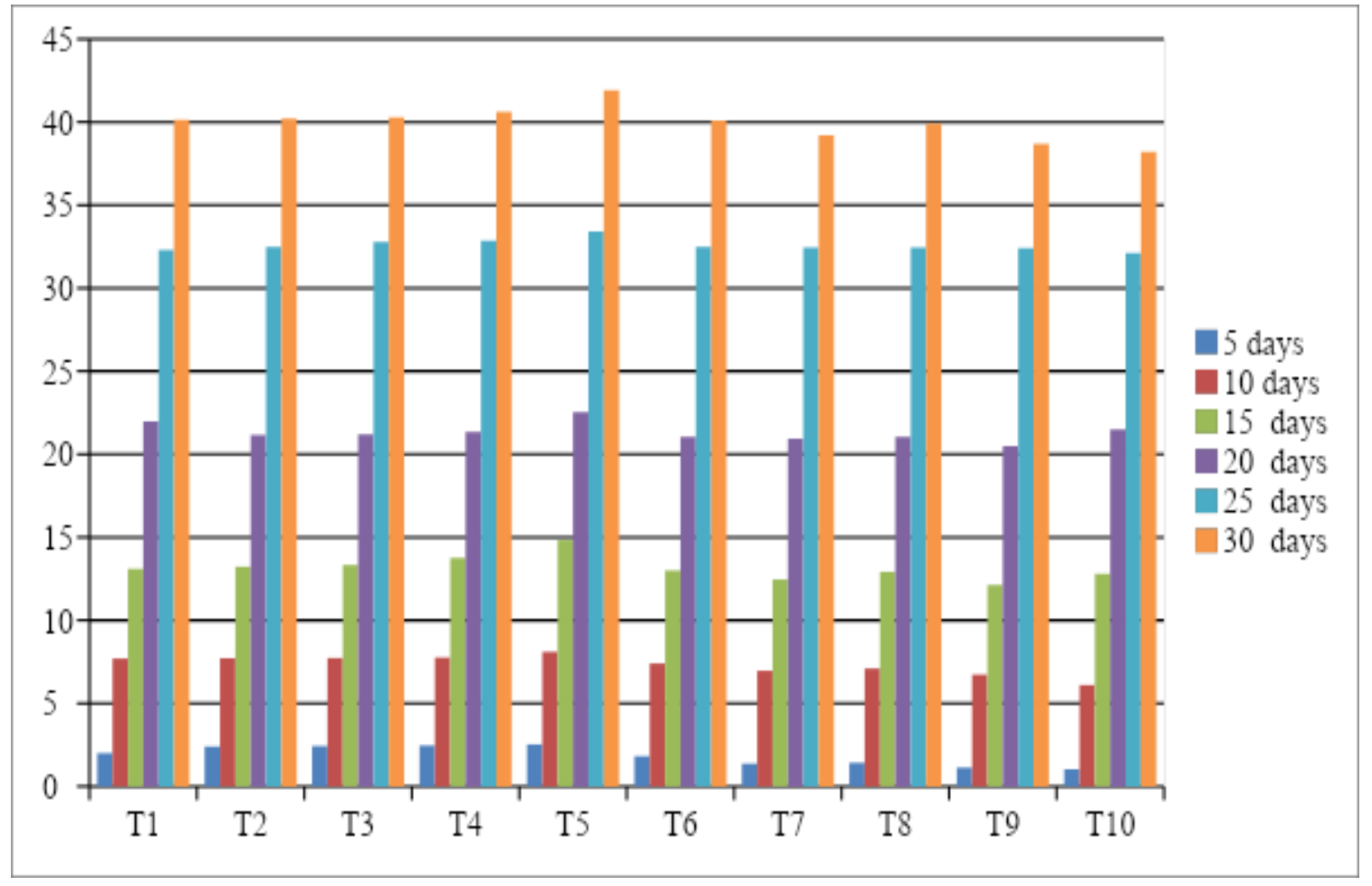


However minimum percent is 50 given by both gypsum and rhizobium similar findings was reported by Horsfall and Lukens (1971).

As per concern of growth parameter, the maximum plant height is $41.90 \mathrm{~cm}$ given by tubers treated by $T$. harzianum followed by $40.60 \mathrm{~cm}$ by rhizobium.

However the minimum height is $38.70 \mathrm{~cm}$ given by $T$. viride.

\section{Acknowledgements}

This research was supported by Department of Plant Pathology Chandra Shekhar Azad University of Agriculture \& Technology, Kanpur.

\section{References}

1. Christ, B.J. (1991). Effects of Disease Assessment Method on Ranking Potato
Cultivars for Resistance to Early Blight. Plant Dis., 75: 353-356.

2. Monaco, C., Nico, A., Rollan, M. and Urrutia, M. 2001. In vitro effect of fungicides used for controlling tomato early blight on mycoflora antagonists to phylloplane. Investigacion Agraria Produccion Proteccion Vegetales, 16: 325-332.

3. Raza, W., M.U. Ghazanfar, Y. Iftikhar, M.H. Rasheed, K.S. Ahmed and Haider, N. 2016. Management of early blight of tomato through the use of plant extracts. Int. J. Zool. Studies, 1(5): 1-4

4. Singh, P.H., Singh B.P. and Singh, L. (2003). Need based application of fungicides for management of early blight in potato. J. Indian Potato Assoc., 30 (1-2): 143-144.

5. Horsfall, J. G. and Lukens, J. (1971). Different temperature for separate Alternaria solani. Phytopathology. 61: 129

\section{How to cite this article:}

Anurag Shukla and Ved Ratan. 2019. Management of Early Blight of Potato by Using Different Bioagents as Tuber Dressing and its Effect on Germination and Growth. Int.J.Curr.Microbiol.App.Sci. 8(06): 1965-1970. doi: https://doi.org/10.20546/ijcmas.2019.806.233 